\title{
Preservice Teachers' Motivations for the Accounting Teaching Profession: Fit-Choice Findings from a Selected Public Universities in Ghana
}

\author{
Leticia Sam \\ Department of Arts and Social Sciences Education, University of Cape Coast, Ghana \\ Daniel Agyapong \\ Department of Marketing and Supply Chain Management, University of Cape Coast, Ghana \\ Andze Ahmed Tahir \\ Department of Arts and Social Sciences Education, University of Cape Coast, Ghana \\ John Kojo Sam \\ Directorate of physical Development and Estate Development (DPDEM), \\ University of Cape Coast, Ghana
}

\begin{abstract}
Teacher motivation influences teachers' actions in the classroom and student achievement. Grounded in the FITChoice model, the study investigated the perception of preservice teachers about accounting teaching profession. Again, the study examined the motivational factors that attract preservice teachers to the accounting teaching profession. Descriptive cross-sectional survey design was used for the study. The population comprised all final year Bachelor of Education accounting students of University of Cape Coast and University of Education, Winneba (i.e 2018/19 academic year). Proportionate stratified sampling technique was utilised to engage 226 preservice teachers (students) in a survey. FIT-Choice scale developed by Watt and Richardson (2007) was adapted and used. Data to answer research question 1 and 2 were analysed using mean and standard deviation. Findings revealed that preservice teachers have a positive perception about the accounting teaching profession. Again, findings showed that preservice teachers were attracted to the accounting teaching profession predominantly by social utility value and personal utility values. The study recommends that academic advisors, counsellors and faculty must continue to strengthen career guidance and counselling among students (i.e., preservice teachers) to sustain the positive view that preservice teachers have about the accounting teaching profession.
\end{abstract}

Keywords: Accounting, Teaching, Motivational factors, Career Choice, Interest

DOI: $10.7176 / \mathrm{JEP} / 12-6-06$

Publication date: February $28^{\text {th }} 2021$

\section{INTRODUCTION}

Well accepted global notion is the fact that teachers can and do make a difference by influencing the lives of students and their orientation to learning. Equally, it has been acknowledged by Governments around the world that quality teachers and teaching are pivotal to the advancement and maintenance of an intelligent, informed citizenry (Richardson \& Watt, 2006). Teachers are indispensable stakeholders in education without whom no country can achieve its educational goals (Salifu, 2013). Because of this important role, attention needs to be given to teacher motivation as one of the important measures of possibly ensuring that highly qualified personnel are attracted to and retained in the teaching profession to provide quality teaching. Teacher motivation is a small but growing area of educational research. Previous studies have revealed that when teachers feel more motivated they exhibit greater planning and organization, more openness to new ideas, a willingness to experiment with new teaching methods, and greater persistence in working with struggling students (Thoonen, Sleegers, Ort, Peetsma, \& Geijsel, 2011; Lam, Cheng, \& Ma, 2009).

Accounting as a service activity serve the function of quantitative information, primarily financial in nature, about economic entities that is intended to be useful in making economic decisions (American Institute of Certified Public Accountants [AICPA], 2009). As part of the service provided, bookkeeping, tax preparation, auditing and other financial information are relevant materials which safeguard organisational progress. According to Cheng (2007) accounting is not merely the language of the enterprise, informing supervisors, but a crucial changer of a country's economic fortunes. The foregoing role make accounting education crucial for every emerging economy. Accounting education is normally seen as providing students with information about how financial books are kept in the form of collecting, recording, summarizing, reporting, analyzing, and auditing the data that will steer the decisions in business (Mustapha \& Ahmed, 2011). In spite of the strides made 
in the worldwide reform in accounting education, there are studies who hold the opinion that, currently, accounting education as a model has failed to focus on developing graduates for successful careers worldwide (Awayiga et al., 2010; Ainsworth, 2001). Is accounting education model failure claim a reality or a perception? Accounting education literature have helped drawn attention to several areas that needed strengthening in accounting education. For example, Apostolou, Dorminey, Hassell, and Watson (2013) pointed out that core professional competencies like communication, analytical skill, critical thinking are relevant ingredients for success in accounting. They further added that offering students opportunities to interact with professionals, through internships, service learning, and mentoring are very important in developing students' professional skills. Moreover, Botcheva, Shih, and Huffman (2009) have emphasized the importance of cultural competence as a central criterion of sound evaluation practices in accounting education. The aforementioned areas provide hope for better accounting education.

Ghana's Financial Accounting education dates back to the days of colonial governance and missionary schools. It was significantly introduced at the Government Boys College (now Mfantsipim) in Cape Coast initially, as bookkeeping to be studied together with shorthand and typewriting as the commercial subjects' curriculum under the colonial administration of Sir

Frederick Gordon Guggisberg (Boateng, 2015; Ministry of Education, 2008). After independence, they were still part of the school curriculum. Commercial subjects were written during the Middle School Leaving Certificate Examination (M.S.L.C.E.). The commercial education curriculum was transmuted to include Financial Accounting as a subject. Till date, the subject accounting has remained an elective subject or major for most students in second cycle and tertiary schools in Ghana. Teaching of accounting subject at the pre-tertiary level has become one of the noble teaching professions that many young people seek ambitiously. As people enrol in universities that train teachers to pursue the dream to become accounting teachers, what at all can be said to be attracting them to the profession? What perception do they have about 'the teaching of accounting'? What motivational factors attract preservice teachers to the accounting teaching profession?

Generally, perceptions of students eventually form part of their beliefs which in turn can influence their career choices (Ferreira \& Santoso 2008; White \& White, 2006). The perception accounting students hold about their intended professional careers in accounting can affect their self-image, attitude towards the career and even their confidence in the profession (Dalci, Arasli, Tümer, \& Baradarani, 2013). Since wrong perceptions can lead to misleading representations, it becomes critically important for accounting students to have a realistic perception of what the accounting profession entails (Byrne \& Willis, 2005). The assumption here is that once 'yet to become teachers' perceptions about accounting teaching is known, practitioner such as accounting educators (especially, at the tertiary schools) curriculum expert, and school counsellors would be better equipped to provide reorientation programmes that would properly inform the preservice accounting teachers. As already alluded to, empirical information regarding motivation behind influx of teachers into the accounting teaching profession or better still why people choose to teach accounting at the pre-tertiary level is quite not known. Studies have been done, especially, in Ghana on the subject, however, the focus of those studies did not answer the already raised questions about why people choose to become teachers of accounting. For example, Mbawuni (2015) worked on students' perception about financial accounting as a profession and not the reasons for students becoming accounting teachers. Prior to Mbawuni's study, Kwarteng (2014) had already explored the level to which senior high school teachers, notably accounting teachers, were motivated to stay committed to duty. Even before, Awayiga, Onumah, and Tsamenyi (2010) had examined the accounting knowledge and skills required by graduates. Other empirical studies conducted in Ghana had being on quality of accounting education (Kwarteng, 2014), professional qualification and instructional practices of accounting curriculum (Osei-Tutu \& Darkwa, 2015), gender and accounting education in Ghana (Aboagye, 2016) as well as students' attitude toward the study of accounting and performance (Bekoe, Owusu, Ofori, Essel-Anderson \& Welbeck, 2018). Clearly there exists a space in knowledge regarding preservice teachers' influx to the teaching profession. This present study responds to the need for such information through the use of FIT-Coice model approach.

\section{LITERATURE REVIEW}

\section{FIT-Choice Model}

The FIT-Choice model is based on the Expectancy-Value work of Eccles and friends which posits that ability and values are important motivations in motivations in foretelling career choices (Eccles, Adler, Futterman, Goff, Kaczala, Meece, \& Midgley, 1983). Drawing from the premise of the model, it is obvious that social dissuasion, prior teaching and learning experiences as well as social influences, play a key role in determining intrinsic motivation that are founded on two sets of intrinsic values that is social utility value and personal utility value. Personal utility values are the extent to which individuals perceive task(s) as relating to their personal goals (Eccles \& Wigfield, 2002). In the context of this model, the constituents of personal utility values include; job security, time for family and job transferability. On the other hand, social utility value has to do with how individual assess the usefulness of what they do in a job (i.e what teachers do in class). The details of what 
constitute social utility value include; shaping the future of pupils or adolescents, promoting social equity, contributing one's quota to society and working with children or adolescents (Watt \& Richardson, 2007). These intrinsic values do not alone influence the choice of a teaching career but other extrinsic values also contribute to such a decision. Examples of extrinsic values are task demand (expert career, high demand) versus task return (social status, salary) on the one hand, and self-perceptions (perceived teaching abilities) versus fall back career factors, among others. Extrinsic values are often known to be benefits attached to one's duties that tend to attract other potential performers of such duties to that profession.

\section{Social factors that determines career path}

Social factors contribute to people decision to pursue a teaching career. These social motivations emanate from extended family members, parents, siblings, social mentors, friends etc, and other social influences (Watt \& Richardson 2008; Watt, Richardson, \& Wilkins, 2014). For purposes of emphasis, an individual may decide to become a teacher because one of their parents is a teacher or someone in their direct social network may have talked so much about the value and importance of a teaching career (Mariscal \& Delgado, 2016). Also, an individual may choose teaching in order to teach a specific content area he/she enjoys or enjoyed learning about (Heinz, 2015). Conversely, an individual may choose not to pursue a teaching career because of the perception that teaching is a less prestigious and lucrative career than other potential options (Watt, Richardson, Klusmann, Kunter, Beyer, Trautwein, \& Baumert, 2012). This make up the point that social factors really play a role in career choice.

\section{External factor that determines career path}

Evidence from multinational studies in the literature suggest numerous external factors that influence a person to choose a teaching profession. For example, Anthony and Ord (2008) in New Zealand, and Claeys (2011) in the US have already discovered that attractive salaries and job recognition are both influential factors affecting a decision to choose a teaching career (such as an accounting teacher). Interestingly, the studies finding deviates from that of Mathew (2005) in Singapore, and Watt and Richardson (2012) in Australia, which have found, rather, that job security, time for family and desire to make social contributions are the influential and decision factors in a teaching choice. In Ghana, for instance, some studies by Tawia-Armah (2010) and Mensah (2011) have shown that working in rural schools is considerably more difficult and thus more de-motivating than working in urban schools. This is mainly due to unbearable living and working conditions in remote areas. Other studies by Agezo (2010) and Asadullah (2006) have established that teachers who work in Ghanaian schools as natives tend to have higher levels of job satisfaction than their colleagues who are non-natives. This is because locally based teachers are more likely to have supportive extended family and social networks, be known to the community and have higher levels of commitment to promoting education and development activities in the area. Issues about what motivate people to choose the teaching profession has extensively been investigated across the globe, especially, at the point that teacher attrition seems to be an emerging phenomenon (Lawver \& Torres, 2011; William \& Forgasz, 2009). Based on what is discovered in the literature investigating why people choose to become accounting teachers in Ghana is worthwhile exercise.

\section{Perception of accounting students}

Students studying accounting as a major hold many perception ranging from positive to negative. However, the negative perception appears to dominate. For example, some students' perceived accountants as reputable and respected people due to the demands of the profession (Germanou, Hassall, \& Tournas, 2009; Góis \& Brás, 2013). For negative perceptions, they include the fact that accounting people are corrupt, untruthful, and dishonest, often manipulate figures in financial reports, and often do not report the true state of affairs and often hide vital materials in financial reports (Wessels \& Steenkamp, 2009). Prior research has established that people tend to perceive accountants as rigid, people who are too structured and often follow strict regulatory requirements (Parker, 2000; Hunt et al., 2004). Prior perceptions of students concerning accounting profession generally affect career decisions of students. Based on the literature available it appears that almost all the studies conducted focus on students' perception about financial accounting and not accounting teaching as a profession. This study therefore sought to bridge this knowledge gap by investigating the perceptions of students on accounting teaching.

\section{RESEARCH QUESTIONS}

The following research questions were posed to guide the study:

What perceptions do preservice teachers have about the teaching of Accounting?

What motivational factors attract preservice teachers to the teaching of accounting in Ghana? 


\section{RESEARCH METHODS}

Descriptive survey, specifically, cross-sectional design was used for the study. This design was used because of its strength of providing an accurate and objective description of a picture of an on-going situation or real-life situation (Leedy and Ormrod, 2005). The target population of the study comprised all undergraduate final year accounting education students' in the University of Cape Coast and University of Education, Winneba, thus level 400 in the 2018/19 academic year. They were estimated to be 549 in number, however, for the purpose of convenience and also to ensure a more detailed study of the elements involved, the researcher used a sample size of 226 which was in agreement with Krejcie and Morgan (1970) sampling estimation computation for a population of 549. Sample selection was done using proportionate stratified sampling procedure with a common ratio of 0.411 . The study adapted the FIT-Choice (Factors Influencing Teaching Choice) scale which was developed and used in an Australian context among pre-service teachers by Watt and Richardson (2007). The scale had two parts (A and B). Part 'A' elicited responses regarding preservice teachers' perception about accounting teaching in Ghana. Part ' $\mathrm{B}$ ' sought to find participants' views on influential factors affecting teacher motivation which intend attract them to the profession. The multidimensional scale had an overall Cronbach alpha reliability coefficient of .92 . Before the questionnaires were administered to respondents, they were assured of confidentiality and anonymity of all information. Respondents' voluntary consent to participate was also sought. Two days were used for the data collection exercise. The response rate was $100 \%$. Data to answer research questions 1 and 2 were analysed using mean and standard deviation.

\section{RESULTS OF THE STUDY}

What perceptions do preservice teachers have about the teaching of Accounting?

This research question sought to investigate preservice teachers' perception about 'accounting teaching' as a profession. Responses to answer this research question were solicited using FIT-Choice questionnaire of 4-point Likert scale. Summary of responses are shown in Table 1.

Table 1-Respondents perception about accounting teaching profession

\begin{tabular}{llc}
\hline Statements & Mean & Std. \\
\hline Teaching of accounting requires high level of expert knowledge. & 3.5 & .90 \\
Teaching of accounting is hard work. & 3.3 & .70 \\
Accounting teachers always have heavy workload. & 2.5 & .80 \\
Teaching of accounting is emotionally demanding. & 1.9 & .91 \\
Teaching of accounting is a well-respected career. & 3.1 & .89 \\
Teaching of accounting is regarded among high status occupation in society. & 2.8 & 1.1 \\
I do think accounting teachers feel valued in society. & 2.9 & .88 \\
No individual can convince me enough that accounting teaching is not a good profession. & 2.9 & .98 \\
I see people who teach accounting as happy people. & 2.5 & 1.1 \\
I think taking a decision to become an accounting teacher is a dream come true. & 2.4 & .60 \\
\hline Mean of Means/Average SD & 2.7 & .89 \\
\hline
\end{tabular}

Source: Field Data, (2020)

Results from Table 1 shows that preservice teachers who are university students had the perception $(\mathrm{M}=3.5$, $\mathrm{SD}=.90$ ) that teaching of financial accounting at the senior high school level requires expertise knowledge. They also had the belief $(\mathrm{M}=3.3, \mathrm{SD}=.70)$ that teaching of accounting subject is a hard work. Again, the preservice teachers think $(\mathrm{M}=, \mathrm{SD}=)$ teaching of accounting is a well-respected career for which they yearn to join. Moreover, the yet to become teachers had the perception $(\mathrm{M}=2.9, \mathrm{SD}=.88)$ that accounting teachers are valued in the society and further feel $(\mathrm{M}=2.9, \mathrm{SD}=.98)$ accounting teaching is a good profession. On the contrary, the preservice teachers do not believe $(\mathrm{M}=1.9, \mathrm{SD}=.91)$ teaching of accounting is emotionally demanding. The preservice teachers also ruled out $(\mathrm{M}=2.4, \mathrm{SD}=.60)$ the fact that getting a job to teach accounting is a dream come true. All in all, the mean of means scores $(\mathrm{M}=2.7, \mathrm{SD}=.89)$ appears to suggest that preservice teachers had positive perception about the accounting teaching profession. The average standard deviation of .89 also suggest that respondents' responses were homogeneous in form.

What motivational factors attract preservice teachers to the teaching of accounting in Ghana?

This research question sought to examine the motivational factors that attract preservice teachers to become accounting teachers. FIT-Choice questionnaire was used. Summary of the responses are indicated in Table 2. 
Table 2-Motivational factors attracting respondents to accounting teaching profession

\begin{tabular}{lcc}
\hline Statements & Mean & Std. \\
\hline I have the qualities of a good accounting teacher & 3.0 & .60 \\
I have good teaching skills & 3.4 & .91 \\
I love to the idea of been an accounting teacher & 3.3 & .81 \\
I chose to teach accounting because I had no other career to pursue. & 1.9 & .91 \\
I feel teaching of accounting is a secured job. & 3.5 & .82 \\
I feel teaching will provide me with a reliable income. & 2.1 & .68 \\
A teaching job will allow me to choose where I want to live. & 3.2 & .87 \\
As an accounting teacher I will have lengthy holidays & 2.9 & .89 \\
Teaching of accounting will allow me to influence the next generation of accounting professionals. & 2.4 & .70 \\
Teaching of accounting will help me to make a worthwhile social contribution. & 2.5 \\
I want a job that involves working with the youth which accounting teaching offers me. & 2.6 \\
I have had positive learning experiences & 2.8 \\
I think my family welcomes the idea of I becoming an accounting teacher. & 3.1 & .83 \\
\hline Mean of Means/ Average SD & 2.8 \\
\hline Source: Field & .88 \\
\hline
\end{tabular}

Source: Field Data, (2020)

From Table 2, results indicate that preservice teachers are motivated $(\mathrm{M}=3.5, \mathrm{SD}=.82)$ by the fact that a job as an accounting teacher is a secured one. Perceived good teaching skills $(\mathrm{M}=3.4, \mathrm{SD}=.91)$ of preservice teachers also account for their choice of desiring to teach accounting. Preservice teachers feel attracted $(\mathrm{M}=3.3$, $\mathrm{SD}=.81)$ to the teaching of accounting because they simply love the idea. Moreover, the fact that they would have the opportunity to choose where they want to live add up $(\mathrm{M}=3.2, \mathrm{SD}=.87)$ to the motivating aspect of teaching accounting. Families of preservice teacher willingly accept $(\mathrm{M}=3.1, \mathrm{SD}=.88)$ the profession of accounting teaching hence they prefer to be one of such professionals. Furthermore, preservice teachers believed $(\mathrm{M}=3.0, \mathrm{SD}=.60)$ they had good qualities of accounting teachers hence it motivates them to be one. Generally, the mean of means $(\mathrm{M}=2.8, \mathrm{SD}=.81)$ points to the fact that quite a number of good qualities motivate preservice teachers to become accounting teachers. The average standard deviation score is an indication that responses were homogeneous.

\section{DISCUSSION}

The motivations behind university Bachelors of Education accounting students (preservice teachers) desire for a teaching profession in accounting has long remain a guess talk without any empirical revelation. This work was committed to first of all, investigating the perception of preservice teachers about the accounting teaching profession. Findings of the study revealed that preservice teachers generally had a positive perception about the accounting teaching profession. For purposes of emphasis, they (preservice teachers) generally believe that the teaching of accounting requires high expertise knowledge. They also have the view that accounting teaching is a hard work and well-respected career in society. For respondents accounting teachers are values within the society and this may be because the profession is a good one. Unlike other accounting related jobs (such as financial accounting, auditing, tax accounting etc) that have attracted a lot of negative perceptions, accounting teaching has been seen differently by preservice teachers. This positive perception corroborates with studies in the literature that hold the general view that accounting related professions are reputable and well-respected in the society (Germanou, Hassall, \& Tournas, 2009; Góis \& Brás, 2013). The positive perception about accounting teaching job agrees with the FIT-Choice model personal utility value that suggests that people actually take teaching jobs because they feel the job is honourable that fit their interest (Watt \& Richardson, 2007).

The second objective was also to uncover the motivational factors that attract preservice teachers to the accounting teaching profession. Findings indicated that job security, preservice teachers perceived skills, the joy to be called accounting teacher (intrinsic career value), opportunity to choose where to live (job transferability) and the fact that one has the opportunity to make a worthwhile impact into society (social contribution) make up motivational factors that attract preservice teachers to the accounting teaching profession. The findings concur with Mathew (2005) in Singapore, and Watt and Richardson (2012) in Australia, which have found, rather, that job security, time for family and desire to make social contributions are the influential and decision factors in a teaching choice. Further, the study findings flows into the FIT-Choice model's social utility value. On the social utility model, people become teachers based on the motivation that they will get the opportunity to shape the future of others which will be their contribution to society (Watt \& Richardson, 2007). The job security, perceived abilities of preservice teacher and job transferability aspect of the findings also feed directly into the personal utility value of the FIT-Choice model propounded by Watt and Richardson, (2007).

\section{CONCLUSIONS}

Base on the findings of the study, it can be concluded that preservice teachers studied are more likely to exhibit 
good work attitude and commitment in the near future when they take up the mantle as accounting teachers since they have a positive attitude toward the teaching profession. Their perception about the teaching profession definitely has implication their work attitude and their performance on the job. Again, the study can conclude that preservice teachers in the near future when they get on the teaching job, are more likely to stay on the teaching job since the motivation factors that attracted them to the profession were predominantly intrinsic in nature.

\section{RECOMMENDATIONS}

Based on the findings, the study recommends that:

Academic advisors, counsellors and faculty must continue to strengthen career guidance and counselling among students (i.e., preservice teachers) to sustain the positive view that preservice teachers have about the accounting teaching profession. This has implication for quality teaching of the accounting subject at the pre-tertiary level.

The Ministry of Education through Ghana Education Service should continue to improve both external career value (task demand and salary) and internal career value (workshops and seminars) to help sustain the attractive picture of the accounting teaching profession to the youth.

\section{REFERENCES}

Aboagye, A. A. (2016). Gender and Accounting Education in Ghana (Doctoral dissertation, University of Ghana).

Agezo, K. C. (2010). Why teachers leave teaching: The case of pre-tertiary institutions in Ghana. International Journal of Educational Reform, 19, 51-52.

Ainsworth, P. (2001). Changes in accounting curricula: discussion and design. Accounting Education, 10(3), 279-297.

American Institute of Certified Public Accountants (AICPA). (2009). Omnibus proposal of professional ethics division interpretations and rulings. Available at: http://www.aicpa.org/download/ethics/Final_Ethics_Exposure_Draft 090209.pdf.

Apostolou, B., Dorminey, J. W., Hassell, J. M., \& Watson, S. F. (2013). Accounting education literature review (2010-2012). Journal of Accounting Education, 31(2), 107-161.

Asadullah, M. N. (2006). Pay differences between teachers and other occupations: Some empirical evidence from Bangladesh. Journal of Asian Economics, 17(6), 1044-1065.

Awayiga, J. Y., Onumah, J. M., \& Tsamenyi, M. (2010). Knowledge and skills development of accounting graduates: The perceptions of graduates and employers in Ghana. Accounting Education: an international journal, 19(1-2), 139-158.

Awayiga, J. Y., Onumah, J. M., \& Tsamenyi, M. (2010). Knowledge and skills development of accounting graduates: The perceptions of graduates and employers in Ghana. Accounting Education: an international journal, 19(1-2), 139-158.

Bekoe, R. A., Owusu, G. M. Y., Ofori, C. G., Essel-Anderson, A., \& Welbeck, E. E. (2018). Attitudes towards accounting and intention to major in accounting: a logistic regression analysis. Journal of Accounting in Emerging Economies.

Boateng, C. O. (2015). The influence of mathematics ability on students' academic performance in financial accounting (Doctoral dissertation, university of cape coast).

Botcheva, L., Shih, J., \& Huffman, L. C. (2009). Emphasizing cultural competence in evaluation: A processoriented approach. American Journal of Evaluation, 30(2), 176-188.

Byrne, M., \& Willis, P. (2005). Irish secondary students' perceptions of the work of an accountant and the accounting profession. Accounting Education: an international journal, 14(4), 367-381.

Cheng, K. W. (2007). The curriculum design in universities from the perspective of providers in accounting education. Education, 127(4).

Claeys, L. (2011). Teacher motivation to teach and to remain teaching culturally and linguistically diverse students. The University of Texas at San Antonio.

Dalcı, I., Araslı, H., Tümer, M., \& Baradarani, S. (2013). Factors that influence Iranian students' decision to choose accounting major. Journal of Accounting in Emerging Economies.

Eccles, J. S., \& Wigfield, A. (2002). Motivational beliefs, values, and goals. Annual review of psychology, 53(1), $109-132$

Ferreira, A., \& Santoso, A. (2008). Do students' perceptions matter? A study of the effect of students' perceptions on academic performance. Accounting \& Finance, 48(2), 209-231.

Germanou, E., Hassall, T., \& Tournas, Y. (2009). Students' perceptions of accounting profession: work value approach. Asian Review of Accounting.

Góis, C. G., \& Brás, F. A. (2013). In the aftermath of the Bologna process: exploring the master students perceptions on accounting in two Portuguese higher education institutions. Educade: revista de educación 
en contabilidad, finanzas y administración de empresas, (4), 34-55.

Heinz, M. (2015). Why choose teaching? An international review of empirical studies exploring student teachers' career motivations and levels of commitment to teaching. Educational Research and Evaluation, 21(3), 258-297.

Hunt, S. C., Falgiani, A. A., \& Intrieri, R. C. (2004). The nature and origins of students' perceptions of accountants. Journal of Education for Business, 79(3), 142-148.

Krejcie, R. V., \& Morgan, D. W. (1970). Determining sample size for research activities. Educational and Psychological Measurement, 30, 607-610.

Kwarteng, J. T. (2014). Motivating senior high school accounting teachers to stay at post in Ghana: A tripartite elemental analysis. International Journal of Scientific and Research Publications, 414.

Lam, S. F., Cheng, R. W. Y., \& Ma, W. Y. (2009). Teacher and student intrinsic motivation in project-based learning. Instructional Science, 37(6), 565.

Lawver, R. G., \& Torres, R. M. (2011). Determinants of Pre-Service Students' Choice to Teach Secondary Agricultural Education. Journal of Agricultural Education, 52(1), 61-71.

Leedy, P. D., \& Ormrod, J. E. (2005). Practical research. Pearson Custom.

Mariscal, D. C., \& Delgado, F. J. H. (2016). Main Motivations of Students of Childhood Education and Primary Education to Become Teachers. Mediterranean Journal of Social Sciences, 7(6), 153.

Mathew, L. J. (2005). The impact of higher salaries and performance-related pay on retention rate of graduate teachers of public schools in Singapore (Masters in education). Monash University, Australia.

Mbawuni, J. (2015). Examining students' feelings and perceptions of accounting profession in a developing country: The role of gender and student category.

Mensah, F. M. (2011). A case for culturally relevant teaching in science education and lessons learned for teacher education. The Journal of Negro Education, 296-309.

Mustapha, M., \& Ahmad, A. C. (2011). Agency theory and managerial ownership: Evidence from Malaysia. Managerial Auditing Journal.

Parker, L. D. (2000). Environmental costing: a path to implementation. Australian Accounting Review, 10(22), 43-51.

Parsons, J. E., Adler, T. F., Futterman, R., Goff, S. B., Kaczala, C. M., Meece, J. L., \& Midgley, C. (1983). Expectancies, values, and academic behaviors. Achievement and achievement motives, 75-146.

Richardson, P. W., \& Watt, H. M. (2006). Who chooses teaching and why? Profiling characteristics and motivations across three Australian universities. Asia-Pacific Journal of Teacher Education, 34(1), 27-56.

Salifu, I. (2013). Improving teacher identity and professional practice: Does motivation matter? In J. Madden \& R. Smith (Eds.), Teacher education dialogue: Innovations: Proceedings of conference held from 2 to 3 August, 2012 at Southern Cross University, Australia.

Tawia-Armah, G. (2010). Teacher motivation in selected senior high schools in the Kwabre District of the Ashanti Region (Doctoral dissertation, University of Cape Coast).

Thoonen, E. E., Sleegers, P. J., Oort, F. J., Peetsma, T. T., \& Geijsel, F. P. (2011). How to improve teaching practices: The role of teacher motivation, organizational factors, and leadership practices. Educational administration quarterly, 47(3), 496-536.

Watt, H. M., \& Richardson, P. W. (2008). Motivations, perceptions, and aspirations concerning teaching as a career for different types of beginning teachers. Learning and instruction, 18(5), 408-428.

Watt, H. M., \& Richardson, P. W. (2012). An introduction to teaching motivations in different countries: comparisons using the FIT-Choice scale. Asia-Pacific Journal of Teacher Education, 40(3), 185-197.

Watt, H. M., Richardson, P. W., \& Wilkins, K. (2014). Profiles of professional engagement and career development aspirations among USA preservice teachers. International Journal of Educational Research, $65,23-40$

Watt, H. M., Richardson, P. W., Klusmann, U., Kunter, M., Beyer, B., Trautwein, U., \& Baumert, J. (2012). Motivations for choosing teaching as a career: An international comparison using the FIT-Choice scale. Teaching and teacher education, 28(6), 791-805.

Watt, H., Richardson, P., \& Tysvaer, N. (2007). Profiles of beginning teachers' professional engagement and career development aspirations. In Dimensions of Professional Learning (pp. 155-175). Brill Sense.

Wessels, P. L., \& Steenkamp, L. P. (2009). An investigation into students' perceptions of accountants. Meditari: Research Journal of the School of Accounting Sciences, 17(1), 117-132.

Williams, J., \& Forgasz, H. (2009). The motivations of career change students in teacher education. Asia-Pacific Journal of Teacher Education, 37(1), 95-108.

Yeboah-Appiagyei, K., Osei-Tutu, J., \& Darkwa, B. F. (2014). Effects of professional qualifications of financial accounting teachers on academic performance of financial accounting students in Tamale Metropolis of Ghana. International Journal of Research in Social Sciences, 4(8), 83-91 